\title{
Optimizing biomethanation of a lignocellulosic biomass using indigenous microbial-cellulases systems
}

\author{
Chima Ngumah $^{1 *}$, Jude OGbulie ${ }^{1}$, Justina ORJi ${ }^{1}$, EkPerechi Amadi ${ }^{1}$, Chris Nweke ${ }^{1}$, Jude Allino ${ }^{2}$ \\ ${ }^{1}$ Department of Microbiology, Federal University of Technology, Owerri, Nigeria \\ ${ }^{2}$ Department of Chemistry, Federal University of Technology, Owerri, Nigeria
}

\begin{abstract}
Studies on enhancing biomethanation were performed to ascertain whether amending lignocellulosic biomass waste with indigenous microbial-cellulases systems will improve biomethane output. To evaluate this, gastrointestinal contents of slaughtered beef cattle were treated with inocula derived from the guts of giant African land snail (Archachatina marginata) and worker termites (Coptotermes formosanus), individually as well as combined. The fed-batch method operating at prevailing ambient room temperatures $\left(30 \pm 2^{\circ} \mathrm{C}\right)$ for a hydraulic retention time (HRT) of 60 days was adopted. Feedstock slurry without amendment, amended with Archachatina marginata-derived inoculum, amended with Coptotermes formosanus-derived inoculum, and amended with Archachatina marginata: Coptotermes formosanus (50:50\%) mixed inocula yielded cumulative biomethane of $65.26 \mathrm{ml} / \mathrm{g}$ VS, $63.21 \mathrm{ml} / \mathrm{g} \mathrm{VS}, 125.99 \mathrm{ml} / \mathrm{g} \mathrm{VS}$, and $97.16 \mathrm{ml} / \mathrm{g} \mathrm{VS}$, respectively. Physicochemical analysis of feedstock and digestates revealed increased reductions in lignin, hemicelluloses, and celluloses (lignocelluloses) in trials amended with microbial-cellulases systems. This study revealed that among the experiments assayed, the trial amended with the cellulases system from Coptotermes formosanus yielded the highest cumulative biomethane.
\end{abstract}

Key words: anaerobic digestion, biogas, bio-augmentation, recalcitrant biowaste

\section{Introduction}

Biomethanation is a process in which an organic matter is anaerobically converted to biogas (methane) through the activities of microorganisms (Angelidaki et al., 2011). It can be applied to virtually all biological materials (biomass), but fractions with low degradability will limit the production of biomethane and also lower the efficiency of the process. According to Blom and coworkers (2012), lignocellulosic biomass, such as hardwood, softwood, vegetation, industrial, and agricultural residues, is the most abundant material for biomethanation and the most renewable biomass with a worldwide annual production of $1 \times 10^{10}$ million tons (Sánchez and Cardona, 2008). They comprise cellulose, hemicelluloses, lignin, and other minor components. Both celluloses and hemicelluloses fractions are polymers of sugars, and thereby serve as a source of fermentable sugars (Hermsen et al., 2010). Lignocellulose biomass can be used as feedstock for biomethanation; however, its com- pact crystalline structure, and the fact that lignin physically shields the cellulose and hemicelluloses parts, makes it recalcitrant to anaerobic digestion (AD) (McKendry, 2002; Mossier et al., 2005). A suitable treatment that will increase the degradability or digestibility of lignocellulosic materials is required to optimize the overall biomethanation process.

Biogas is a mixture of methane (45-75\%) and carbon dioxide (25-55\%), the actual proportions of which depend on the feedstock (substrate) and the processes employed. Methane content should be $\geq 40 \%$ for biogas to be flammable (Monnet, 2003). In addition to methane and carbon dioxide, biogas also contains small amounts $(\leq 3 \%)$ of impurities, such as hydrogen sulfide, ammonia, carbon monoxide, and other gases (Monnet, 2003). Biogas technology, also known as $\mathrm{AD}$ technology, is based on biological processes involving breakdown of the organic matter in the absence of oxygen and stabilization of these materials by conversion to biogas and nearly stable

\footnotetext{
${ }^{*}$ Corresponding author: Department of Microbiology, Federal University of Technology Owerri, P.M.B. 1526 Owerri, Nigeria; e-mail: ccngumah@yahoo.com
} 
residues (Marchaim, 1992). Since organic material is converted to biogas in $\mathrm{AD}$, where methane is the major component of interest, it is also referred to as biomethanation (Angelidaki et al., 2011).

Currently, one of the most important prerequisites for sustainable development is the production of appropriate and adequate renewable energy which can substitute fossil fuels. Biomethane produced from biomass waste (biowaste) is a promising renewable energy source, which is already in use in several countries (Blom et al., 2012).

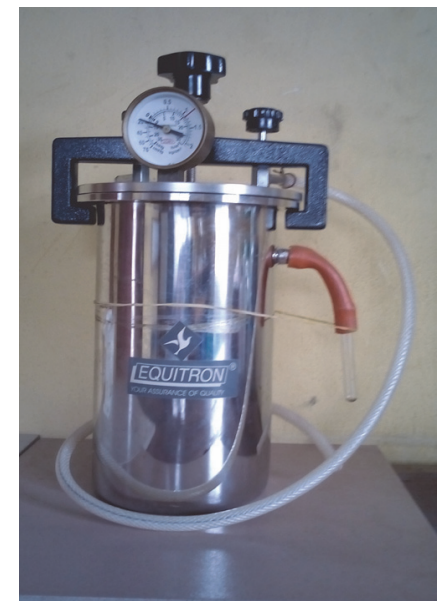

Fig. 1. Equitron stainless steel anaerobic culture jar (model: 8151)

This study investigates the effect of different indigenous microbial-cellulases systems on the biomethane yields of a lignocellulosic biomass subjected to AD. It was developed to provide an affordable and sustainable means of optimizing biomethane yield from lignocellulosic biomass. The reasons to carry out this study include the continuous renewable availability of lignocellulosic biowaste feedstock; low energy input required in operating an anaerobic digester at mesophilic temperatures; the fact that the microbial inocula employed in this study is readily available and can be easily amplified; the low cost and minimum skill requirements in operating a simple anaerobic digester (Ngumah et al., 2013a); and all the accruable benefits of waste management, renewable energy, biofertilizer, among others.

Fresh gut contents of slaughtered beef cattle were used as feedstock and the microbial inocula used were derived from the guts of Archachatina marginata (giant African land snail) and Coptotermes formosanus (worker termite).
Laboratory scale fed-batch (discontinuous) method of $\mathrm{AD}$ operating at prevailing room temperatures $\left(30 \pm 2^{\circ} \mathrm{C}\right)$ was employed.

Several methods are available for optimizing the biomethanation process for the most efficient waste treatment and maximum resource generation. Its main aim is to reduce the HRT and/or maximize the product output. According to Uzodinma and coworkers (2011) and Goswami (http://home.eng.iastate.edu/ tge/ce421-521/ ShyamGoswami.pdf), the various optimization methods employed include use of additives, pretreatment of substrates, codigestion, use of inocula, upgrading process designs, and manipulating operating parameters. However, the particular treatment(s) adopted depend on the rate-limiting factor(s).

Many workers have shown that the use of bio-augmentation has tremendously enhanced the digestibility of lignocellulosic biomass. For instance, inoculating switch grass with swine, dairy, and poultry manure resulted in volatile solids removal of about $58 \%, 24 \%$, and $31 \%$, respectively, during a 30-day dry AD batch trial (Ahn and Smith, 2008). Nda-Umar and Uzowuru (2011) also showed that the addition of abattoir effluent markedly improved the digestion of fruit waste in a 49-day batch $\mathrm{AD}$ operating at ambient temperature. In another study, biomethane obtained from corn bract increased by about $174.03 \%$ and $290.91 \%$ when seeded with cow and swine dung, respectively, in an $\mathrm{AD}$ batch process at ambient temperature for 35 days (Uzodinma et al., 2011). Similarly, abattoir cow liquor waste was shown to increase biogas production obtained from brewery spent grain by 172.73\% (Wankhade et al., 2012). Studies on the bioconversion of lignocellulosic residues by pure cultures after 5 days retention time at $30^{\circ} \mathrm{C}$ revealed reduction in initial cellulose content: a reduction of $28.2 \%$ was obtained by treatment with Trichoderma viride, $14.4 \%$ with Aureobasidium pullulans, $37.85 \%$ with Sporotrichum sp., and $28.2 \%$ with Papulospora sp. (Amaral Collaco, 1981, 1984; Amaral Collaco, 1988). The ability of white rot fungi to degrade plant residues was investigated by many researchers and found to be very effective (Coughlan and Amaral Collaco, 1990).

In biogas production from lignocellulosic biomass, microorganisms are able to utilize a wide range of organic compounds, such as pentoses, hexoses, fatty acids, proteins, and lipids (Brun, 2010). Lignin is known as a major factor to determine the extent of biomass degra- 
dation in anaerobic conditions. Biological treatment methods are considered as effective and cheap means of delignification (Chandler and Jewell, 1980). Lignin degradation that increases the surface area of the cellulose is frequently used to develop higher susceptibility toward microbes and enzymes (Komilis and Ham, 2003). Ceriporiopsis subvermispora (a white rot fungus) is identified as "the superior" biopulping fungus that can degrade lignin without intensively breaking the cellulose (Akhtar et al., 1992). Other fungi used for the biological treatment of lignocellulosic biomass are Phanerochaete chrysosporium, Trametes versicolor, Trametes hirsuta, and Bjerkandera adusta (Sun and Cheng, 2002).

\section{Materials and methods}

\section{Sample collection}

\section{Feedstock}

Fresh gut contents (gastrointestinal contents, GIC) of slaughtered and dissected beef cattle were collected within 90 minutes of slaughtering from an open abattoir (along Owerri-Elele Dual Carriage Express) at Obinze autonomous community, Owerri West LGA (Owerri metropolis), Imo State. Using a modified version of Eziuzor and Okpokwasili (2009), the feedstock was carefully collected in a 10 litre lidded plastic can using a stainless steel hand trowel (all instruments and containers were thoroughly washed with soap water, rinsed several times with clean water, and then surface-sterilized by scrubbing with (3\%) acid-alcohol).

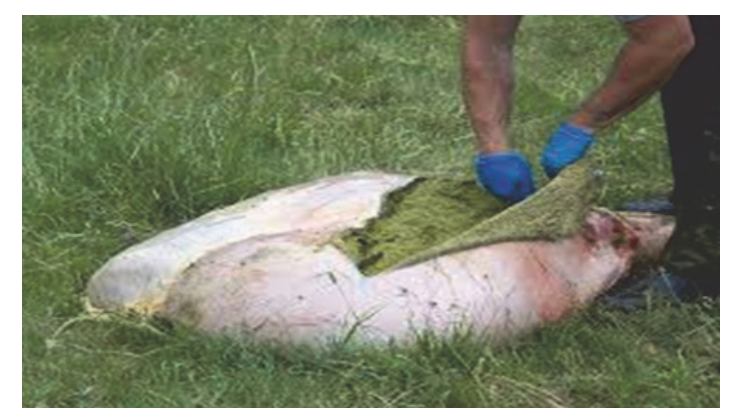

Fig. 2. Fresh Gastrointestinal contents of slaughtered beef cattle

\section{Microbial-cellulases systems}

Active giant African land snails (Archachatina marginata) were purchased from "Eke-Onuwa," a local Market in Owerri municipal LGA, Imo State. These snails were kept in a tree-shaded portion of a grass lawn, and securely covered with a $60-\mathrm{cm}$ diameter locally made palmfrond basket. They were fed ad libitum with fresh pawpaw leaves daily and fresh drinking water for 7 days (Ademolu et al., 2013).

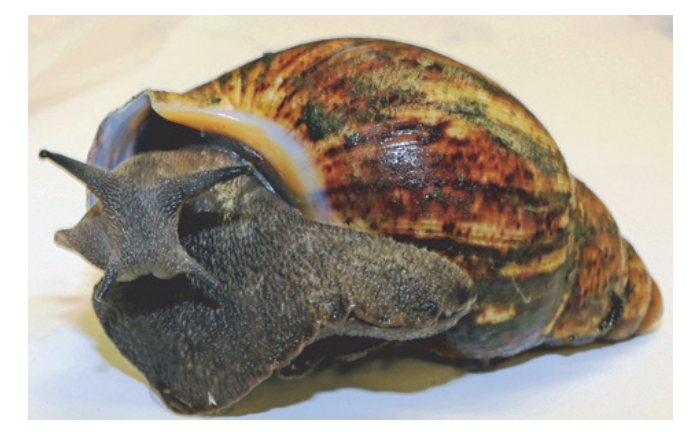

Fig. 3. African land snail (Archachatina marginata)

Live worker termites (Coptotermes formosanus) were collected using clean forceps from termite-infested wood in Owerri metropolis, and transported in a clean secured perforated opaque plastic container. Live termites were processed within 3 hours of collection.

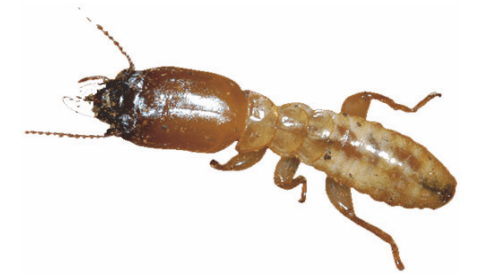

Fig. 4. Worker termite (Coptotermes formosanus)

\section{Preparation of inocula}

The termites were surface-sterilized by soaking in $70 \%$ ethanol for 3 minutes and then rinsed in sterile distilled water. About $1 \mathrm{~g}$ of aseptically macerated and decapitated termites (in a sterile boiling tube using a sterile glass rod) was homogenized in 10 -ml sterile $0.85 \% \mathrm{NaCl}$ solution. About $0.5 \mathrm{ml}$ of this homogenate was mixed with $4.5 \mathrm{ml}$ sterile soy casein digest broth containing extra-pure microcrystalline cellulose $(2 \mathrm{~g} / \mathrm{l})$ and incubated at ambient room temperature $\left(30 \pm 2^{\circ} \mathrm{C}\right)$ for 24 hours (Upadhyaya et al., 2012).

Using a modified technique of Oyeleke et al. (2012), snails were washed with clean tap water and their outer shells were scrubbed with $70 \%$ ethanol for surface steri- 
lization. They were later aseptically de-shelled and dissected to reveal the guts. These guts were aseptically macerated, and $10 \mathrm{~g}$ of the resulting pulp was homogenized in $100-\mathrm{ml}$ sterile $0.85 \% \mathrm{NaCl}$ solution. About 1-ml homogenate was mixed with 9-ml sterile soy casein digest broth containing extra-pure microcrystalline cellulose $(2 \mathrm{~g} / \mathrm{l})$ and incubated at ambient room temperature $\left(30 \pm 2{ }^{\circ} \mathrm{C}\right)$ for 24 hours. Later, the stock inocula of termite and snail guts were stored at $4^{\circ} \mathrm{C}$ until required (Abu-Dehrieh et al., 2011).

\section{Preparation of feedstock slurries (ingestates)}

To prepare feedstock slurry, $300 \mathrm{~g}$ of thoroughly mixed gastrointestinal contents of beef cattle was homogenized in 300-ml sterile distilled water (Abubakar and Ismail, 2012). Feedstock slurries were prepared in separate $10 \times 1$-cm lid-perforated cylindrical plastic cans. These plastic cans were previously washed with soap and clean water and surface-sterilized by scrubbing with $70 \%$ ethanol.

\section{Experimental setup}

Stainless steel Equitron anaerobic culture jars of 12 $\times 20 \mathrm{~cm}$ (model: 8151 ) were used as batch reactors (digesters). Each of the labeled feedstock slurries was placed into a correspondingly labeled anaerobic culture jar.

Triplicate slurries of gut contents of beef cattle were prepared in four sets: first set had 10-ml sterile distilled water (no inoculum) added to it (C); the second set had $10 \mathrm{ml}$ of $50 \%$ diluted snail gut-derived stock inoculum added to it and homogenized (CS); the third set had $10 \mathrm{ml}$ of $50 \%$ diluted termite gut-derived stock inoculum added to it and homogenized (CT), while the fourth set had a combination of $5 \mathrm{ml}$ each of $50 \%$ diluted snail gutderived and $50 \%$ diluted termite gut-derived inocula added to it and homogenized (CST). Anaerobiosis was achieved in these batch reactors using the candle jar method as described by Jensen and Trager (1977). Labeled bioreactors were placed on a stable level table and operated at prevailing ambient room temperatures $\left(30 \pm 2{ }^{\circ} \mathrm{C}\right)$ for a HRT of 60 days. The contents of each bioreactor were manually mixed by gently swirling the bioreactors daily once.

\section{Measurement and analysis of gaseous products}

Biogas production was indicated by readings on the pressure gauge of each bioreactor. Gas samples were measured using a modified version of Nda-Umar and Uzowuru (2011) as described by Ngumah and coworkers (2013b). Biogas was measured by promptly passing the accumulated generated gas via a tube through a clear solution of filtered saturated calcium hydroxide solution $(2 \mathrm{~g} / \mathrm{l})$ in a transparent calibrated cylinder by quickly opening the outlet valve fully. Displaced calcium hydroxide solution was recorded as the biogas volume. The biomethane content of the biogas was obtained by allowing the securely covered setup to stand for $24 \mathrm{~h}$, and the remaining displaced gas volume after the upward replacement of calcium hydroxide solution was recorded as the biomethane volume. The carbon dioxide content was computed as the difference between the biogas and biomethane volumes.

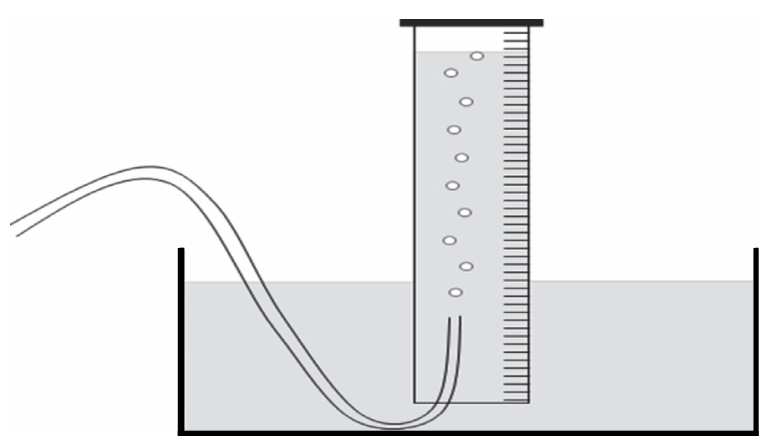

Fig. 5. Methane measurement over saturated, filtered lime water in an inverted calibrated cylinder

Samples of biogas from each bioreactor were also analyzed using a Landtec Biogas 5000 analyzer to determine the percentage compositions of methane, carbon dioxide, ammonia, and hydrogen sulfide.

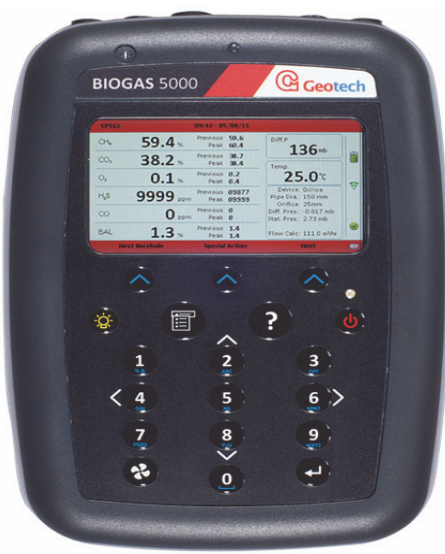

Fig. 6. Landtec Biogas 5000 analyzer 


\section{Physicochemical analyzes}

$\mathrm{pH}$ and temperature of feedstocks and digestates were determined simultaneously using a calibrated digital Hanna instrument (model: H196107). Total solids and volatile solids were determined using a standard method described by Pillai (2009). Other physicochemical analyzes (including fiber analysis to determine lignin, hemicelluloses, and cellulose) of the feedstock and digestates were estimated following standard procedures as outlined by Handbook of reference methods for plant analysis (Kalra, 1998).

\section{Statistical analyzes}

The means of replicated experiments were calculated, and the means of the differences between treatments were tested using one way analysis of variance I (ANOVA I). The expression "significant difference" referred to significant difference at $P \leq 0.05$. Pearson correlation analysis and simple regression analysis were performed to determine (if any) the quality of significant associations existing between biomethane yields and selected physicochemical parameters.

\section{Mathematical modeling}

The kinetics of biomethane yields were evaluated using the modified Gompertz model on the assumption that the rate of biomethane production in batch condition is equivalent to specific growth rate of the methanogens in the digester (Budiyono et al., 2014):

$$
P=A \exp \{\exp [U e / A(\lambda-t)+1]\}
$$

where

$P$-cumulative biomethane yield at a digestion time $t$ days (ml/g VS)

$A$ - biogas production potential (ml/g VS)

$U$-maximum biogas production rate $(\mathrm{ml} / \mathrm{g} \mathrm{VS} /$ day)

$\lambda$ - lag-phase period or minimum time to produce biomethane (days)

$e$ - mathematical constant (2.718282)

\section{Results}

\section{Biomethane production of different trials in 60 days hydraulic retention time batch digesters}

The quantities of biomethane produced at different intervals by various digesters ( 60 days HRT) are shown in Figure 1 . The four trials, namely feedstock slurry without amendment (microbial inoculum), amended with giant African snail-derived inoculum, amended with worker termitederived inoculum, and amended with mixed (50:50\%) snail-termite-derived inocula. All digesters produced biomethane at every given interval. The feedstock inoculated with termite-derived inoculum (CT) gave the highest biomethane yields of $17.27 \mathrm{ml} / \mathrm{g}$ VS on days 40 and 45 , while the un-inoculated digester $(\mathrm{C})$ yielded the lowest of $0.44 \mathrm{ml} / \mathrm{g}$ VS on day 60 . The results of the cumulative biomethane yields of different trials after 60 days batch digestion are shown in Figure 2. The feedstock with Coptotermes formosanus-derived inoculum yielded the highest cumulative biomethane of $125.99 \mathrm{ml} / \mathrm{g}$ VS.

At 5\% level of significance, ANOVA showed that there was no significant difference among the means of biomethane yields for the un-amended trial, the trial amended with snail-derived inoculum, and the trial amended with mixed (50:50\%) snail-termite-derived inocula. Sánchez and Cardona, (2008). However, there was a significant difference between the trial amended with termite-derived inoculum, the un-amended trial, and the trial amended with snail-derived inoculum (Table 1).

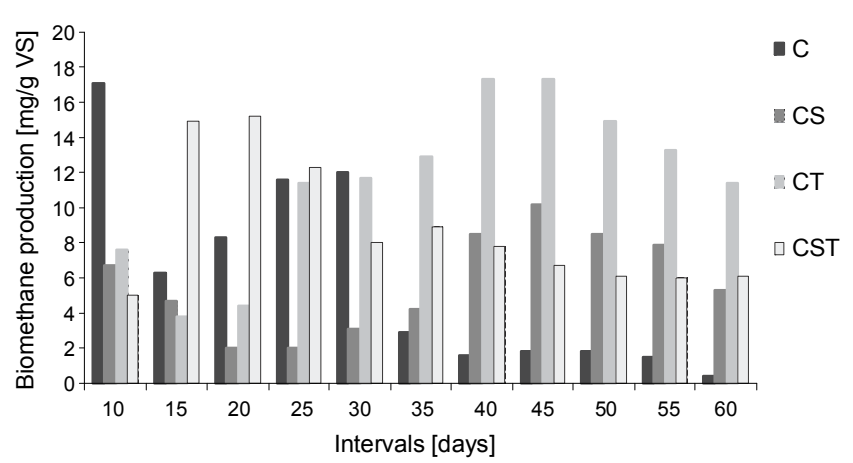

Fig. 7. Biomethane production of different trials at various time (days) intervals; digesters containing: $\mathrm{C}$ - gut contents of slaughtered beef cattle; CS - C + giant African snail (Archachatina marginata)-derived inoculum; CT - C + worker termite (Coptotermes formosanus)-derived inoculum; CST $\mathrm{C}+$ giant African snail (Archachatina marginata): worker termite (Coptotermes formosanus) [50:50\%] mixed inocula

\section{Cumulative percentage composition of gaseous constituents of biogas produced}

The cumulative percentages of biomethane, carbon dioxide, hydrogen sulfide, and ammonia components of biogas generated by different trials are provided in Table 2 . These results show that the digesters containing feedstock and termite-derived inoculum (CT) and feed- 


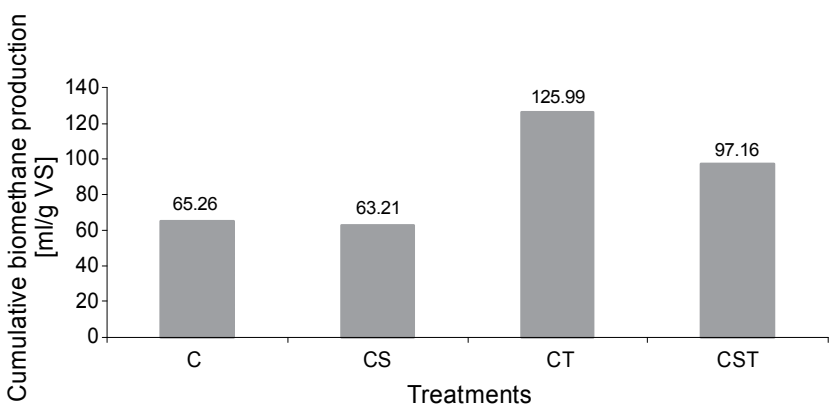

Fig. 8. Cumulative biomethane productions of different trials in 60 days HRT batch digestions; digesters containing: $\mathrm{C}$ - gut contents of slaughtered beef cattle; $\mathrm{CS}-\mathrm{C}+$ giant African snail (Archachatina marginata)-derived inoculum; CT - C + worker termite (Coptotermes formosanus)-derived inoculum; CST - C + giant African snail (Archachatina marginata): worker termite (Coptotermes formosanus) (50:50\%) mixed inocula

stock and snail-derived inoculum (CS) gave the highest and the smallest biogas yields of $158.33 \mathrm{ml} / \mathrm{g}$ VS and $81.79 \mathrm{ml} / \mathrm{g}$ VS, with corresponding biomethane contents of $79.49 \%$ and $75.23 \%$, respectively.

\section{Kinetic parameters of different trials derived from modified Gompertz model}

Table 3 shows the results of kinetic parameters (biomethane production potential, maximum biomethane production rate, and lag-phase period) of different trials. The treatment with termite-derived inoculum (CT) gave the highest biomethane production potential $(206.36 \mathrm{ml} / \mathrm{g}$ VS), the highest maximum biomethane production rate (5.64 $\mathrm{ml} / \mathrm{g} \mathrm{VS} /$ day), and the lowest lag-phase period (4.1 days).

\section{Comparative physicochemical analyzes of feedstock and digestates of different anaerobic digestion trials}

Table 4 displays the quantitative contents of 11 physicochemical parameters of the feedstock used and digestates derived from different $\mathrm{AD}$ trials. Reductions in total solids, volatile solids, total carbohydrates, and chemical oxygen demands in the digestates of all the trials were observed. On the other hand, $\mathrm{pH}$ values increased in all the digestates tested.

\section{Relative lignin, hemicelluloses, and cellulose levels in feedstock and digestates of different anaerobic digestion trials}

Table 5 shows the relative quantities of lignin, hemicelluloses, and cellulose in feedstock and digestates. All the digestates recorded reduced lignin, hemicelluloses, and cellulose contents after AD.

\section{Correlation analysis}

Table 6 shows the degree of association among biomethane yields, total solids, fiber contents, lignin contents, hemicelluloses contents, cellulose contents, fats, and proteins (of digestates). The association between biomethane yields and total solids of digestates was highly significant.

\section{Discussion}

Biogas produced from biomass (especially from waste materials) is a promising renewable energy source. Though biomethanation can be virtually applied to all biomass, lignocellulosic biomass is the most abundant substrate. Accumulation of lignocellulosic wastes in large quantities leads, or contributes, to many environmental issues. On the other hand, the conversion of these materials into renewable fuels presents great potential in gradually reducing dependency on nonrenewable fossil fuel resources (Chum et al., 1985). Due to their chemical composition, including high sugar content, lignocellulosic wastes can be converted to a number of valueadded products such as ethanol, biogas, lignin, and organic acids and enzymes (Mussatto and Teixeira, 2010). A number of researches are focused on converting biomass into saleable constituents in a market competitive, sustainable, and environmentally friendly manner (Hermsen et al., 2010). A treatment that breaks down compact and crystalline structure of lignocelluloses and removes lignins enhances the volatilization of the resulting material, resulting in improved methane production during the subsequent $\mathrm{AD}$ process (Blom et al., 2012).

In this work, four sets of trials (experiments) were conducted concurrently. Discontinuous (fed-batch) AD was conducted in anaerobic jars (digesters/bioreactors) at ambient room temperatures $\left(30 \pm 2^{\circ} \mathrm{C}\right)$ for an HRT of 60 days. At regular intervals, the digesters were assayed for biomethane production; the initial gas readings were noted on day 10 , while subsequent readings were noted every 5 days. Each trial set had a different ingestate: feedstock slurry (C) only, feedstock slurry + snail-derived inoculum (CS), feedstock slurry + termite-derived inoculum (CT), and feedstock slurry + mixed $(50: 50 \%)$ snail-termite-derived inocula (CST).

The trial amended with termite-derived inoculum had its cumulative biomethane yields enhanced by $93.06 \%$ with a highest output of $125.99 \mathrm{ml} / \mathrm{g}$ VS (Fig. 2), 
Table 1. Analysis of variance for means of biomethane yields for different trials

\begin{tabular}{c|c|c|c|c}
\hline \multirow{2}{*}{} & \multicolumn{4}{|c}{ Trials } \\
\cline { 2 - 5 } & $\mathrm{C}$ & $\mathrm{CS}$ & $\mathrm{CT}$ & $\mathrm{CST}$ \\
\hline $\begin{array}{c}\text { Biomethane }\left(\mathrm{CH}_{4}\right) \text { yields } \\
{[\mathrm{ml} / \mathrm{g} \mathrm{VS}]}\end{array}$ & $65.26^{\mathrm{b}}$ & $63.21^{\mathrm{b}, \mathrm{c}}$ & $125.99^{\mathrm{a}}$ & $97.16^{\mathrm{a}, \mathrm{b}}$ \\
\hline
\end{tabular}

a, b, c - superscripts of the same letter are not significantly different at $5 \%$ level of significance $(P>0.05)$; digesters containing: $\mathrm{C}-$ gut contents of slaughtered beef cattle; $\mathrm{CS}-$ $\mathrm{C}+$ giant African snail (Archachatina marginata)-derived inoculum; $\mathrm{CT}-\mathrm{C}+$ worker termite (Coptotermes formosanus)-derived inoculum; CST - C + giant African snail (Archachatina marginata): worker termite (Coptotermes formosanus) $(50: 50 \%)$ mixed inocula

Table 2. Comparative biogas analysis of different trials

\begin{tabular}{l|c|c|c|c|c}
\hline Trial & $\begin{array}{c}60 \text { days cumulative } \\
\text { biogas production } \\
{[\mathrm{ml} / \mathrm{g} \text { VS] }}\end{array}$ & $\begin{array}{c}\text { Biomethane } \\
{[\%]}\end{array}$ & $\begin{array}{c}\text { Carbon dioxide } \\
{[\%]}\end{array}$ & $\begin{array}{c}\text { Hydrogen sulfide } \\
{[\mathrm{ppm}]}\end{array}$ & $\begin{array}{c}\text { Ammonia } \\
{[\%]}\end{array}$ \\
\hline $\mathrm{C}$ & 86.18 & 75.66 & 24.28 & 0.033 & 0.01 \\
\hline $\mathrm{CS}$ & 81.79 & 75.23 & 22.72 & 0.030 & 0.014 \\
\hline $\mathrm{CT}$ & 158.33 & 79.49 & 20.43 & 0.047 & 0.013 \\
\hline $\mathrm{CST}$ & 122.48 & 79.23 & 20.67 & 0.040 & 0.013 \\
\hline
\end{tabular}

digesters containing: $\mathrm{C}$ - gut contents of slaughtered beef cattle; $\mathrm{CS}-\mathrm{C}+$ giant African snail (Archachatina marginata)-derived inoculum; CT - C + worker termite (Coptotermes formosanus)-derived inoculum; CST $\mathrm{C}+$ giant African snail (Archachatina marginata): worker termite (Coptotermes formosanus) $(50: 50 \%)$ mixed inocula

Table 3. Kinetic parameters of different trials derived from modified Gompertz model

\begin{tabular}{l|c|c|c|c}
\hline Trial/Treatment & $A$ & $U$ & $\lambda$ & $R^{2}$ \\
\hline $\mathrm{C}$ & 66.96 & 3.76 & 8.84 & 0.986 \\
\hline $\mathrm{CS}^{*}$ & & & & \\
\hline $\mathrm{CT}$ & $206.36^{\mathrm{h}}$ & $5.64^{\mathrm{h}}$ & $4.1^{1}$ & 0.999 \\
\hline $\mathrm{CST}$ & $102.16^{\mathrm{h}}$ & $4.33^{\mathrm{h}}$ & $6.53^{1}$ & 0.991 \\
\hline
\end{tabular}

* nonlinear regression could not be applied; cumulative biomethane plot failed to yield a plateau at 60 days HRT; $\mathrm{h}$ - higher than $\mathrm{C} ; 1-$ lower than C; $A$ - biomethane production potential (ml/g VS); $U$ - maximum biomethane production rate (ml/g VS/day); $\lambda$ - lag-phase period or minimum time to produce biomethane (days); $R^{2}$ - coefficient of determination; digesters containing: $\mathrm{C}$ - gut contents of slaughtered beef cattle; $\mathrm{CS}-\mathrm{C}+$ giant African snail (Archachatina marginata)-derived inoculum; $\mathrm{CT}-\mathrm{C}+$ worker termite (Coptotermes formosanus)-derived inoculum; CST - C + giant African snail (Archachatina marginata): worker termite (Coptotermes formosanus) (50:50\%) mixed inocula

followed by the trial amended with mixed $(50: 50 \%)$ snailtermite-derived inocula had biomethane yields enhanced by $48.88 \%$, and the trial amended with snail-derived inoculum had biomethane yields reduced by $3.14 \%$. ANOVA at 5\% significance level $(P>0.05)$, however, showed no significant difference in the means of biomethane yields between the trials amended with termite-derived inoculum and that amended with the mixed snail-termitederived inocula. No significant difference in biomethane yields was found between the trial without any amend- 
Table 4. Physicochemical analyzes of feedstock and digestates of four AD trials

\begin{tabular}{l|c|c|c|c|c}
\hline \multicolumn{1}{c}{ Physicochemical } & \multirow{2}{*}{$\begin{array}{c}\text { Deedstock } \\
\text { Parameter }\end{array}$} & Fesigestates & \multicolumn{4}{c}{ CST } \\
\cline { 3 - 6 } & $\mathrm{C}_{0}$ & $\mathrm{C}$ & $\mathrm{CS}$ & $\mathrm{CT}$ & $7.4\left(28^{\circ} \mathrm{C}\right)$ \\
\hline $\mathrm{pH}$ (temperature) & $6.2\left(26^{\circ} \mathrm{C}\right)$ & $7.6\left(27^{\circ} \mathrm{C}\right)$ & $7.6\left(27^{\circ} \mathrm{C}\right)$ & $7.7\left(27^{\circ} \mathrm{C}\right)$ & 6.51 \\
Total solids (\%m/m, wet mass) & 13.99 & 7.42 & 7.09 & 4.55 & 1.38 \\
Volatile solids (\%m/m, wet mass) & 11.39 & 5.15 & 1.82 & 0.65 & 84.16 \\
Moisture (\%m/m, wet mass) & 69.75 & 72.65 & 77.65 & 78.11 & 2.43 \\
Ash (\%m/m, wet mass) & 2.46 & 2.60 & 2.13 & 2.34 & 0.88 \\
Crude proteins (\%m/m, wet mass) & 1.14 & 1.49 & 1.23 & 1.31 & 1.41 \\
Crude fats (\%m/m, wet mass) & 1.63 & 1.22 & 1.14 & 1.29 & 8.07 \\
Total carbohydrates (\%m/m, wet mass) & 25.44 & 19.17 & 14.92 & 14.38 & 48.45 \\
Calorific value (kcal/g, dry mass) & 120.98 & 93.58 & 94.82 & 74.37 & 4.628 \\
Biological oxygen demand (g/L) & 3.7 & 3.816 & 3.642 & 4.046 & 46 \\
Chemical oxygen demand (g/L) & 32.90 & 25.58 & 27.43 & 25.57 & 23.72 \\
\hline
\end{tabular}

$\mathrm{C}_{0}$ - feedstock; $\mathrm{C}$ - digestate of gut contents of slaughtered beef cattle without inoculum treatment; $\mathrm{CS}$ - digestate of $\mathrm{C}+$ Archachatina marginata-derived inoculum; CT - digestate of C + Coptotermes formosanus-derived inoculum; CST - digestate of C + Archachatina marginata: Coptotermes formosanus (50:50\%) mixed inocula

Table 5. Comparative lignin, hemicelluloses, and cellulose levels in feedstock and digestates

\begin{tabular}{l|c|c|c|c|c}
\hline \multirow{2}{*}{} & \multicolumn{5}{|c}{$\% \mathrm{~m} / \mathrm{m}$ dry mass of feedstock } \\
\cline { 2 - 6 } & feedstock & $\mathrm{C}$ & $\mathrm{CS}$ & $\mathrm{CT}$ & CST \\
\hline Lignin & 2.243 & 1.124 & 1.0116 & 0.735 & 1.038 \\
\hline Hemicelluloses & 24.643 & 16.164 & 13.389 & 10.541 & 15.013 \\
\hline Cellulose & 31.217 & 21.773 & 19.584 & 13.719 & 8.892 \\
\hline
\end{tabular}

$\mathrm{C}$ - digestate of gut contents of slaughtered beef cattle without inoculum treatment; CS - digestate of $\mathrm{C}+$ Archachatina marginata-derived inoculum; $\mathrm{CT}$ - digestate of $\mathrm{C}+$ Coptotermes formosanus-derived inoculum; CST - digestate of $\mathrm{C}+$ Archachatina marginata: Coptotermes formosanus $(50: 50 \%)$ mixed inocula

Table 6. Pearson's correlation analysis showing the coefficient of determination $\left(R^{2}\right)$ between different parameters

\begin{tabular}{|c|c|c|c|c|c|c|c|c|c|c|}
\hline & Biomethane & $\begin{array}{l}\text { Total } \\
\text { solids }\end{array}$ & Fiber & Lignin & $\begin{array}{c}\text { Hemi- } \\
\text { celluloses }\end{array}$ & Cellulose & Fats & Proteins & $\begin{array}{c}\text { Carbo- } \\
\text { hydrates }\end{array}$ & $\begin{array}{l}\text { Energy } \\
\text { value }\end{array}$ \\
\hline \multicolumn{11}{|l|}{ Biomethane } \\
\hline Total solids & $0.912^{* * *}$ & & & & & & & & & \\
\hline Fiber & 0.331 & 0.545 & & & & & & & & \\
\hline Lignin & 0.728 & $0.937^{* * *}$ & 0.608 & & & & & & & \\
\hline Hemicelluloses & 0.514 & 0.778 & 0.526 & $0.941^{* * *}$ & & & & & & \\
\hline Cellulose & 0.510 & 0.275 & 0.026 & 0.138 & 0.067 & & & & & \\
\hline Fats & 0.392 & 0.135 & 0.031 & 0.020 & 0.002 & 0.805 & & & & \\
\hline Proteins & 0.071 & 0.006 & 0.378 & 0.0003 & 0.001 & 0.724 & 0.473 & & & \\
\hline Carbohydrates & 0.194 & 0.067 & 0.213 & 0.021 & 0.010 & 0.865 & 0.582 & $0.964^{* * *}$ & & \\
\hline Energy value & 0.371 & 0.136 & 0.080 & 0.032 & 0.001 & $0.945^{* * *}$ & $0.929 * * *$ & 0.717 & 0.823 & \\
\hline $\begin{array}{l}\text { Biological } \\
\text { oxygen demand }\end{array}$ & 0.402 & 0.196 & 0.070 & 0.091 & 0.044 & $0.984^{* * *}$ & 0.750 & 0.824 & $0.937 * * *$ & $0.931^{* * *}$ \\
\hline $\begin{array}{l}\text { Chemical } \\
\text { oxygen demand }\end{array}$ & 0.219 & 0.034 & 0.054 & 0.003 & 0.072 & 0.563 & $0.929 * * *$ & 0.312 & 0.375 & 0.764 \\
\hline
\end{tabular}

$* * *$ very significant $\left(R^{2} \geq 0.900\right)$ 
ment (control) and that amended with snail-derived inoculum. Significant difference was observed, however, in biomethane yields between trials amended with termitederived inoculum and those amended with snail-derived inoculum and the un-amended trial (control) - Table 1. ANOVA 1 for the means of percentage compositions of carbon dioxide, hydrogen sulfide, and ammonia levels showed no significant difference $(P>0.05)$ among all the trials performed.

Applying modified Gompertz model (equation) to the nonlinear regression analysis of cumulative biomethane yields of the different trials revealed that the most efficient process was the trial-amended with termite-derived inoculum. This treatment, in a 60 days retention time digestion, provided the highest cumulative biomethane yield, the highest biomethane production potential, the highest maximum biomethane production rate, the lowest lag-phase period, and the highest coefficient of determination $\left(R^{2}=0.999\right)$ - the best predictable pattern.

Different trials gave different biomethane peak production periods. The trial without any treatment (control) had its peak production between days 1 and 10, with $50 \%$ of total biomethane yield $\left(\mathrm{P}_{50}\right)$ estimated to be produced by day 22 ; the trial treated with snail-derived inoculum had its peak production between days 41 and 45 , with $50 \%$ of total biomethane yield $\left(\mathrm{P}_{50}\right)$ estimated to be produced by day 41 ; the trial treated with termitederived inoculum had peak production periods between days $36-40$ and $40-45$, with $50 \%$ of total biomethane yields $\left(\mathrm{P}_{50}\right)$ estimated to be produced by day 38 ; while the trial treated with mixed snail-termite-derived inocula had its peak production between days 16 and 20 , with $50 \%$ of total biomethane $\left(\mathrm{P}_{50}\right)$ estimated to be produced by day 26 . The trial without treatment and the one treated with mixed snail-termite-derived inocula had their $\mathrm{P}_{50}$ after their peak production periods; while the trials treated with snail-derived inoculum and the one treated with termite-derived inocula had their $\mathrm{P}_{50}$ within their peak production period. The different periods observed for attaining maximum yield in different trials can be attributed to the time required by the various microbial communities to acclimatize. This appears to be supported by the fact that the un-amended trial (with single autochthonous microbial consortium) recorded the earliest peak production period and $\mathrm{P}_{50}$. Lag period can be attributed to a sudden increase in a number of competent microorganisms, with high production rates at- tained when participating microbes have acclimatized (Monaghan et al., 1999). The microbial communities added from the different inocula may have boosted cellulases and methanogenesis-propelling enzymes activities (Monaghan et al., 1999). Nopharatana and coworkers (2007) and Abubakar and Ismail (2012) proposed, however, that biomethane production does not necessarily depend on total viable counts or degree of microbial diversities, but rather on specific microbial growth.

In addition to harboring an effective cellulases system, termites also have an efficient ligninases system (Wong et al., 2014). A higher disruption of lignin will render more hemicelluloses and cellulose available for digestion. Some fungi and Gram-negative bacteria have been reported to produce ligninases (Vernam and Evans, 2000).

The use of snail-derived inoculum either individually or in combination with termite-derived inoculum had reduced biomethane outputs. The reason for this is not quite clear; however, such reductions in biomethane output can be due to the inability of the microbial communities to acclimatize within the 60 days retention trial period. Schnurer and Jarvis (2009) reported that reduced biomethane output can be due to the presence of inhibitors.

The level of biomethane yields from the un-amended trial showed that gastrointestinal contents of slaughtered beef cattle used in this work possess high potency as a feedstock for profitable biomethane production. This is most likely due to its rich, diverse, and specialized microbial community; high nutrient levels; and proper $\mathrm{C}: \mathrm{N}$ balance (Mittal, 2006). The relative lignin, hemicelluloses, and cellulose contents before and after $\mathrm{AD}$ (compensating for total solids reductions after $\mathrm{AD}$ ) are shown in Table 5. Our data revealed that lignin, hemicelluloses, and cellulose contents were considerably reduced in the digestates of all the trials. The highest reductions of lignins and hemicelluloses occurred in the trial amended with termite-derived inoculum, while the highest reduction in cellulose occurred in the trial amended with mixed snail-termite-derived inocula. The least reductions in lignins, hemicelluloses, and cellulose occurred in the untreated trial (control). Hence all the trials showed various levels of reductions in lignin, hemicelluloses, and cellulose. Total (lignin + hemicelluloses + cellulose) reductions (invariably lignocelluloses reductions) in the digestates were $57.07 \%, 56.98 \%$, 
$41.51 \%$, and $32.77 \%$ for the trial treated with mixed snailtermite-derived inoculum, trial treated with termite-derived inoculum, trial treated with snail-derived inoculum, and the untreated trial (control), respectively. Moreover, the microbial treatments applied in this work increased the percentage reduction of volatile solids from $54.76 \%$ in the digestate of untreated trial (control) to $84.02 \%$, $94.29 \%$, and $87.8 \%$ in the digestates of trials amended with snail-derived inoculum, termite-derived inoculum, and mixed snail-termite-derived inocula, respectively. Thus, all the treatments applied in this work improved biodegradation. Pearson's correlation analysis revealed very strong associations between biomethane yield and some physicochemical parameters, and between some physicochemical parameters (Table 6). Very significant associations $\left(R^{2} \geq 0.900\right)$ were recorded between biomethane yields and total solids, total solids and lignin, biological oxygen demand, and lignin and total carbohydrates, energy (calorific) values, and biological oxygen demand. Lignin also showed very significant associations with hemicelluloses. Pearson's correlation analysis showed that the rate of biomethanation was very strongly and inversely correlated with rate of digestion/degradation of biomass/feedstock/substrate, as reported also by Chen and Hashimoto (1978).

\section{Conclusion}

Results were obtained and analyzed from four fedbatch trials of $\mathrm{AD}$ (biomethanation) of a lignocellulosic biomass (gastrointestinal contents of slaughtered beef cattle), namely trial without amendment, amended with Archachatina marginata (snail)-derived cellulases system, amended with Coptotermes formosanus (termite)derived cellulases system, and amended with mixed (50:50\%) snail-termite-derived cellulases systems. Among these, the trial amended with the termite-derived cellulases system gave the highest biomethane output. Nonlinear regression analysis using modified Gompertz model also revealed that treatment with termite-derived cellulases system gave the best kinetic parameters: the highest biomethane production potential, the highest maximum biomethane production rate, the least lagphase period, and best (highest) coefficient of determination $\left(R^{2}\right)$. Physicochemical analysis revealed that amending the lignocellulosic feedstock with termite-derived inoculum also gave the highest degraded digestate, as indicated by the lowest total solids, volatile solids, lignin, and hemicelluloses recorded.

\section{Acknowledgment}

The authors wish to acknowledge and thank Tertiary Education Trust Fund (TETFund) via the Federal University of Technology Owerri (Nigeria) for its financial assistance.

\section{References}

Abubakar B., Ismail N. (2012) Anaerobic digestion of cow dung for biogas production. ARPN J. Eng. Appl. Sci. 7(2): 169-172.

Abu-Dahrich J., Orozco A., Ahmad M., Rooney D. (2011) The potential of biogas production from grass. [in:] Proceedings of the Jordan International Energy Conference, Amman.

Ademolu K.O., Fakeye O.D., Dedeke G.A., Ajayi O.A., Idowu A.B. (2013) Digestive enzymes in African Giant Land Snail (Archachatina marginata) during aestivation. Arch. Zootec. 62(237): 73-77.

Ahn H.K., Smith M.C. (2008) Biogas production from switch grass - animal manure mixture using dry anaerobic digestion. An ASABE meeting Presentation, Rhode Island, June 29 - July 2.

Akhtar M., Attridge M.C., Blanchette R.A, Myers G.C., Wall M.B., Sykes M.S., Koning J.W., Burgess R.R., Wegner T.H., Kirk T. (1992) Biotechnology in pulp and paper industry. [in:] Proceedings of the $5^{\text {th }}$ International Conference on Biotechnology in the Pulp and Paper Industry. Eds. M. Kuwahara, M. Shimada, Tokyo, University Publishers Ltd., p. 3-8.

Amaral Collaco M.T. (1981) Producao de S.C.P. a partir de repiso de tomate a bagaco de uva cum Geotrichum candidum. Pre-tratamento e hidrolise enzimatica. [in:] $1^{\circ}$ Simposio Nacional NOPROT. Ed. Amaral-Collaco M.T. et al. NOPRAI, Lisboa, p. 194-201.

Amaral Collaco M.T. (1984) Protein enrichment of tomato residues for animal feeding. [in:] Proceedings of the Third European Congress on Biotechnology, Vol. II, Dechema, Verlag-Chemie, Munchen, FRG, 563.

Amaral Collaco M.T. (1988) Physiological studies on microbial bioconversion of tomato pomace syrups. [in:] Proceedings of the Eight International Biotechnology Symposium, IUPAC, Chirac, Paris, A-21, 21.

Angelidaki I., Karakashev D., Batstone D.J., Plugge C.M., Stam A.J. (2011) Biomethanation and its potential methods. Enzymol. 494: 327-351. doi: 10.1016/B978-0-12385112-3.00016-0.

Blom A., Peterson A., Persson T, Johansson L., Jarlsvik T., Jacoby J., Kjellvander H. (2012) Biogas from lignocellulosic biomass. Swedish Waste Management, Rapport U2012:07 (ISSN 1103-4092).

Brun E. (2010) Improved anaerobic digestion of energy crops and agricultural residues. Department of Environmental Engineering , Technical University of Denmark: Lyngby. 
Budiyono I.N., Syaichhurrozi I., Sumardiono S. (2014) Kinetic model of biogas yield production from vinasse at various pH: comparison between modified Gompertz model and first order kinetic model. Res. J. Appl. Sci. Eng. Tech. 7(13): 2798-2805.

Chandler J.A., Jewel W.J. (1980) Predicting methane fermentation degradability. Solar Energy Research Institute, Golden, Colorado.

Chen Y., Hashimoto A.G. (1978) Kinetic o1 methane fermentation. Biotechnol. Bioeng. 8: 269-282.

Chum H.L. et al. (1985) Evaluation o1 pretreatment o1 biomass for enzymatic hydrolysis or cellulose. Solar Energy Research Institute. Colarodo State University.

Coughlan M.P., Collaço M.T.A. (1990) Advancess in biological treatment of ignocellulosic materials. Elsevier Science Publishers Ltd., ISBN 1-85166-542-0.

Eziuzor C.S., Okpokwasili G.C. (2009) Bioremediation of hydrocarbon contaminated mangrove soil in a bioreactor. Nigerian J. Microbiol. 23: 1777-1791.

Goswami (http://home.eng.iastate.edu/ tge/ce421521/ShyamGoswami.pdf).

Hermsen P.F., Huijgen W.J., Lopez L.M., Bakker R.R. (2010) Literature review of physical and chemical pretreatment processes for lignocellulosic biomass. Energy Research Center of Netherlands, ECN-E-10-013.

Jensen J., Trager W. (1977) Plasmodium falciparum in culture: use of outdated erythrocytes and description of the candle jar method. J. Parasit. 63(5): 883-886. http://dx.doi.org/ $10.2307 / 3279900$.

Kalra Y.P.. (1998) Handbook of reference methods for plant analysis. Florida, USA: CRC Press.

Komilis D.P., Ham R.K. (2003) The effect of lignin and sugars to the aerobic decomposition of solids. Waste Manag. 23: 419-423.

Marchaim U. (1992) Biogas processes for sustainable development. FAO. p. 1-99.

Mittal G.S. (2006) Treatment of waste water from abattoirs before land application - a review. Bioresour. Technol. 97(9): 1119-1135.

Mckendry P. (2002) Energy production from biomass (part I): overview of biomass. Bioresour. Technol. 83(1): 37-46.

Monaghan R.L., Gagliardi M.M., Streicher S.L. (1999) [in:] Manual of Industrial Microbiology and Biotechnology, $2^{\text {nd }}$ ed. Eds. Damien A.L. et al., Washington, D.C: ASM, 34.

Monnet F. (2003) An introduction to anaerobic digestion of organic wastes. Final Report (November, 2003), 1-43. Scotland: Remade.

Mossier N., Wyman C., Dale B., Elander R., Lee Y., Holtzapple M., Ladisch M. (2005) Features of promising technologies for pretreatment of lignocellulosic biomass. Bioresour. Technol. 96(6): 673-686. doi: 10.1016/j.biotech.2004. 06.025 .
Mussatto S.I., Teixeira J.A. (2010) Lignocelluloses as raw material in fermentation processes. IBB - Institute for Biotechnology and Bioengineering, Center of Biological Engineering, University of Minho.

Nda-Umar U.I., Uzowuru M.G. (2011) Anaerobic co-digestion of fruit waste and abattoir effluent. J. Biol. Sci. Bioconserv. 3(1): 26-34.

Ngumah C., Ogbulie J., Orji J., Amadi E. (2013a) Potential of organic wastes for biogas and biofertilizer production in Nigeria. Environ. Res. Eng. Manag. 1(63): 60-66.

Ngumah C., Ogbulie J., Orji J., Amadi E. (2013b) Effects of initiating anaerobic digestion of layer-hen poultry dung at sub-atmospheric pressure. Ambiente Agua 8(3): 33-42.

Nopharatana A.P., Pullammanappallil C.W., Clarke P. (2007) Kinetics and dynamic modeling of batch anaerobic digestion of municipal solid waste in a stirred reactor. Waste Manag. 27: 595-603.

Oyeleke S.B., Egwim E.C., Oyewole O.A., John E.E. (2012) Production of cellulose and protease from microorganisms isolated from gut of Archachatina marginata (Giant African Snail). Sci. Technol. 2(1): 15-20. doi: 10.5923/ j.scit.20120201.03.

Pillai S. (2009) A comprehensive laboratory manual for environmental science and engineering. New Age International Publishers Ltd. New Delhi, p. 7-11.

Sánchez O.J., Cardona C.A. (2008) Trends in biotechnological production of fuel ethanol from different feedstocks. Bioresour. Technol. 99(13): 5270-5295. (doi:10.1016/ j.biotech.2007.11.013).

Schnurer A., Jarvis A. (2009) Microbiological handbook for biogas plants. Sweden: Avfall Sverige.

Sun Y., Cheng J. (2002) Hydrolysis of lignocellulosic materials for ethanol production: a review. Bioresour. Technol. 83: 1-11.

Upadhyaya S.K., Manandhar A., Mainali H., Pokhrel A.R., Rijal A., Pradhan B., Koirala B. (2012) Isolation and characterization of cellulolytic bacteria from gut of termite. Rentech Symposium Compendium 1: 14-18.

Uzodinma E.O., Ofoefule A.U., Enwere N.J. (2011) Optimization of biogas fuel production from blending maize bract with biogenic wastes. Amer. J. Food Nutr. 1(1): 1-6.

Vernam A.H., Evans M.G. (2000) Environmental microbiology. ASM Press. Washington, D.C., USA.

Wankhade N.A., Thakre S.B., Dhote A.V., Wankhade P.S. (2012) Enhancement of biogas from abattoir cow liquor waste with some agro-industrial wastes. Int. J. Eng. Res. Appl. (IJERA) 2(5): 1383-1388.

Wong L.J., H'ng P.S., Wong S.Y., Lee S.H., Lum W.C. et al. (2014) Termite digestomes as a potential source of symbiotic microbiota for lignocelluloses degradation: a review. Pakistan J. Biol. Sci. 17(8): 956-963. 